DOI: https://doi.org/10.47405/mjssh.v6i9.997

\begin{tabular}{|c|c|}
\hline & Malaysian Journal of Social Sciences and Humanities (MJSSH) \\
\hline Malaysian Journal of & Volume 6, Issue 9, September 2021 \\
\hline (MJ-SSH) & e-ISSN : 2504-8562 \\
\hline & $\begin{array}{l}\text { Journal home page: } \\
\text { www.msocialsciences.com }\end{array}$ \\
\hline
\end{tabular}

\title{
Pedagogi Terbeza Untuk Pengajaran Guru Terhadap Kepelbagaian Murid
}

\author{
Zurina Mustaffa ${ }^{1}$, Zaharah Hussin ${ }^{1}$, Abdul Muhsien Sulaiman \\ ${ }^{1}$ Fakulti Pendidikan, Universiti Malaya (UM) \\ Correspondence: Zurina binti Mustaffa (zurinamustaffa2020@gmail.com)
}

\begin{abstract}
Abstrak
Beberapa kajian telah menunjukkan terdapat murid kurang menguasai isi pelajaran disebabkan faktor kepelbagaian murid di dalam bilik darjah. Dalam konteks pendidikan, hal ini tidak akan selesai sehingga wujudnya kaedah pengajaran yang baharu yang dapat membantu guru mempelbagaikan kaedah pengajaran yang sesuai untuk kepelbagaian murid di bilik darjah. Antara faktor yang menyumbang kepada murid tidak menguasai isi pelajaran ialah faktor gaya pengajaran guru yang mengajar dengan gaya "one-size-fits-all" tidak sesuai diguna pakai memandangkan murid yang mempunyai kepelbagaian gaya belajar, tahap penguasaan dan berlainan kecerdasan berada di dalam bilik darjah yang sama. Oleh itu, bagi membantu guru dalam menangani masalah murid yang pelbagai di dalam bilik darjah dan guru dapat mengaplikasikan satu bentuk pengajaran yang dapat melengkapi keperluan murid yang pelbagai, satu pendekatan baharu diperkenalkan iaitu melalui Pedagogi Terbeza (Differentiated Pedagogy). Pedagogi Terbeza (Differentiated Pedagogy) merupakan satu konsep pengajaran di mana guru mengubahsuai kandungan iaitu isi pelajaran yang disampaikan oleh guru, proses iaitu strategi pengajaran dan aktiviti pembelajaran, produk merujuk kepada hasil kemahiran yang murid dapat dan dinilai guru dan persekitaran merujuk kepada suasana persekitaran pembelajaran yang kondusif. Elemen-elemen ini akan diubah suai oleh guru mengikut kepelbagaian murid iaitu kesediaan belajar murid, minat murid terhadap pembelajaran dan profil pembelajaran di mana kecenderungan kecerdasan murid dikesan. Kertas konsep ini membincangkan Pedagogi Terbeza (Differentiated Pedagogy) untuk digunakan dalam membantu pengajaran guru mempelbagaikan kaedah pengajaran yang sesuai dengan kepelbagaian murid.
\end{abstract}

Kata kunci: pedagogi terbeza, kepelbagaian murid, kesediaan, minat, profil pembelajaran

\section{Differentiated Pedagogy for Teachers' Teaching against Pupil Diversity}

\begin{abstract}
Several studies have shown that there are students who lack mastery of the content of the lesson due to the diversity of students in the classroom. In the context of education, this will not be completed until there are new teaching methods that can help teachers diversify teaching methods that are appropriate for the diversity of students in the classroom. Among the factors that contribute to students not mastering the content of the lesson is the teaching style factor of teachers who teach with a "one-sizefits-all" style is not suitable to be used as students with a variety of learning styles, levels of mastery and different intelligence are in the same classroom. Therefore, to help teachers in dealing with the problems of diverse students in the classroom and teachers can apply a form of teaching that can meet the needs of diverse students, a new approach is introduced through Differentiated Pedagogy. Differentiated Pedagogy is a teaching concept in which teachers modify the content that is the content
\end{abstract}


of the lesson delivered by the teacher, the process that is teaching strategies and learning activities, the product refers to the skills that students get and evaluated by the teacher and the environment refers to the learning environment. conducive. These elements will be modified by the teacher according to the diversity of students, namely students' readiness to learn, students' interest in learning and learning profile where students' intelligence tendencies are detected. This concept paper discusses Differentiated Pedagogy to be used in helping teachers to diversify teaching methods to suit the diversity of students.

Keywords: differentiated pedagogy, student diversity, readiness, interest, learning profile

\section{Pengenalan}

Pendidikan merupakan asas dalam kecemerlangan hidup dan dapat mengubah taraf kehidupan kepada yang lebih baik. Pendidikan sangat penting kepada semua tanpa mengira agama, bangsa dan tahap penguasaan murid dalam pelajaran, namun kerancakan sistem pendidikan yang berkembang pesat telah menyebabkan terdapat keciciran murid dalam pembelajaran di mana tidak semua murid mampu untuk menguasai dan memahami isi pembelajaran memandangkan mereka mempunyai keupayaan yang pelbagai. Menurut Eka Putri, Ernawati dan Gita (2018) murid mempunyai gaya belajar yang berbeza, oleh itu guru perlu merancang pengajaran harian mengikut kepelbagaian murid di bilik darjah untuk meraikan kemampuan murid yang pelbagai. Impak kepelbagaian murid yang berada di bilik darjah yang sama memerlukan guru bersiap siaga dengan mempelbagaikan kaedah pengajaran bagi memberi hak kepada murid untuk memahami dan menguasai isi pelajaran dan bukannya menghabiskan silibus pelajaran semata-mata (Basirah, Mohd Yakub \& Muhamad Alihanafiah, 2018).

Oleh itu, meraikan kepelbagaian murid di bilik darjah merupakan satu kewajipan kepada guru, hal ini selari dengan kajian Hamir dan Mohamad Hilmi (2019) yang menyatakan guru perlu meraikan kepelbagaian murid kerana dengan meraikan kepelbagaian ini, murid akan terlibat aktif dalam proses pengajaran dan pembelajaran seterusnya matlamat pembelajaran akan tercapai. Kepelbagaian ini jelas disebut oleh Allah Taala dalam ayat surah Ali Imran (3):11 dan surah al- An'am (6):165 yang menyatakan manusia diciptakan dengan kepelbagaian kebolehan akal, roh dan jasad.

Justeru itu, keperluan Pedagogi Terbeza (Differentiated Pedagogy) yang merupakan bentuk pengajaran yang baharu perlu diketengahkan bagi meraikan dan memenuhi keperluan pembelajaran murid mengikut aras kognitif murid yang pelbagai.

\section{Isu Kepelbagaian Murid}

Pemansuhan sistem peperiksaan bagi murid sekolah rendah telah diumumkan oleh Kementerian Pendidikan Malaysia berdasarkan surat siaran Bilangan 14 Tahun 2018 (Kementerian Pendidikan Malaysia, 2018b) yang menyatakan murid tidak akan dinilai melalui peperiksaan tetapi akan dinilai secara holistik oleh guru. Oleh itu kelas pengasingan (streaming class) tidak lagi digunakan di sekolah (Kementerian Pendidikan Malaysia, 2018a) dan murid yang pelbagai aras sikap, minat dan kepelbagaian akan berada di dalam bilik darjah yang sama. Hal ini memberi kesan kepada pemilihan pedagogi guru di mana guru perlu menyediakan perancangan pengajaran yang meraikan kepelbagaian murid di dalam bilik darjah yang sama dan ia memberi kesan yang positif kepada hubungan guru dan murid (Nur Hanani, Mohd Aderi \& Ab Halim, 2013).

Isu kepelbagaian murid juga menjadikan guru akan lebih bersabar kerana guru akan berulang kali menyampaikan isi pengajaran kerana kepelbagaian murid yang berada di bilik darjah yang sama terdiri daripada murid yang pelbagai aras pencapaian, pemahaman dan keupayaan, hal ini senada dengan dapatan kajian Noraini dan Musliha (2018) bahawa pengajaran perlu dilakukan berulang-ulang supaya murid dapat memahami isi kandungan pelajaran, hal ini selari dengan kehendak Rasulullah SAW bahawa etika seorang guru adalah memudahkan urusan muridnya. 
Menerusi kajian-kajian ini mendapati terdapat murid yang pelbagai di dalam kelas mempunyai gaya belajar yang berlainan, hal ini selari dengan kajian (Rahmita, Noor Fajriah \& R.Ati Sukmawati, 2018) yang menyatakan murid-murid mempunyai gaya belajar yang mempunyai kecenderungan ke arah visual, auditori dan kinestetik (VAK), oleh itu tugas guru merancang pengajaran dalam mengakomodasikan ketiga-tiga gaya pembelajaran ini ke dalam proses pengajaran guru.

Selain dari gaya belajar murid yang pelbagai iaitu visual, auditori dan kinestetik, murid juga mempunyai kepelbagaian dari aspek kesediaan, minat dan profil pembelajaran, hal ini selari dengan dapatan kajian Tomlinson (2017) menyatakan kesediaan murid merujuk kepada murid bersedia dari segi pengetahuan, pemahaman dan kemahiran terhadap isi pelajaran yang diajar guru, manakala minat pula merujuk kepada tajuk kandungan yang diajar atau proses pembelajaran yang menaikkan minat dan semangat murid-murid kepada perasaan ingin tahu dan profil pembelajaran pula menunjukkan gaya belajar murid yang paling berkesan. Sehubungan dengan itu, guru memerlukan pengajaran yang berbeza dalam menangani isu kepelbagaian murid di dalam bilik darjah.

\section{Kesediaan}

Kesediaan murid dalam proses pembelajaran sangat penting kerana ia memberi impak yang besar kepada penguasaan murid dalam isi kandungan pelajaran, Santangelo dan Tomlinson (2008) menyatakan kesediaan murid merupakan salah satu faktor yang penting kepada guru dalam mengubah suai pengajaran kerana terdapat tiga faktor utama dalam kesediaan murid-murid dalam pembelajaran iaitu (i) murid belajar dengan tahap pengetahuan latar belakang yang berbeza, (ii) murid juga berbeza dari aspek pengalaman mereka dalam pembelajaran di sekolah dan (iii) murid mempunyai tahap kemahiran yang berbeza dalam isi kandungan yang diajar oleh guru.

Justeru itu, kesediaan juga merupakan suatu proses dari akomodasi fizikal , mental dan emosi dalam melaksanakan sesuatu tindakan, hal ini senada dengan dapatan kajian (Siti Nurliyana Ab Halim, 2015) yang menyatakan kesediaan murid-murid dalam proses pembelajaran sangat penting kerana kesediaan murid mampu memahami dan menguasai isi pelajaran berbanding dengan murid-murid yang tidak bersedia dengan isi pelajaran yang akhirnya akan menyebabkan kekeliruan dan kurang faham tentang isi kandungan pelajaran yang diajar guru.

Elemen kesediaan sangat penting kerana ia merupakan suatu petunjuk permulaan sama ada murid dapat menguasai atau tidak menguasai isi kandungan pelajaran, ini jelas dalam kajian Mat Janudin (2002) yang menunjukkan sekiranya tahap kesediaan pembelajaran murid tinggi, ia akan menghasilkan minat murid untuk belajar adalah tinggi tetapi jika tahap kesediaan belajar murid adalah rendah maka murid tidak akan berminat untuk meneruskan sesi pembelajaran. Murid juga perlu mempunyai tahap kesediaan dalam menghadapi kaedah pengajaran guru yang baharu, Mat Janudin (2002) juga menyatakan kesediaan murid sangat penting dalam menghadapi kaedah pengajaran yang baharu.

Selain itu, kesediaan murid juga dipengaruhi oleh pengetahuan sedia ada murid tentang isi kandungan pelajaran dan pengalaman yang berkaitan dengan isi kandungan pelajaran, hal ini senada dengan kajian Habibah dan Rahil (1990) menunjukkan pengetahuan sedia ada murid sangat penting kerana ia memudahkan murid untuk menguasai isi pelajaran dan seterusnya melancarkan proses aktiviti pembelajaran murid dan murid lebih bersedia untuk meneruskan tajuk pembelajaran yang baharu.

\section{Minat}

Minat merupakan satu elemen yang penting yang menjadi aras penilaian guru dalam mengubah suai isi kandungan pelajaran dan merupakan asas kepada guru dalam merancang proses pengajaran, fenomena ini selari dengan dapatan kajian Santangelo dan Tomlinson (2008) yang menyatakan dua faktor penting yang terkandung dalam minat murid-murid iaitu (i) minat yang mempunyai hubung kait dengan cita-cita murid dan (ii) minat kepada kumpulan rakan sebaya yang akan disertai oleh mereka. 
Manakala hasil dapatan kajian Yulianingsih dan Lumban (2019) minat menunjukkan kecenderungan seseorang murid terhadap sesuatu perkara dan ditambah dengan perasaan yang positif terhadap aktiviti pembelajaran menjadikan murid-murid mudah mengikuti pembelajaran walaupun aktiviti pembelajaran tersebut kompleks dan sukar.

Sehubungan dengan itu, minat belajar sangat penting dalam kalangan murid-murid kerana minat dapat mempengaruhi kesediaan belajar dan tahap penguasaan murid dalam pelajaran, keadaan ini senada dengan dapatan kajian Noor Erma dan Leong (2014) yang menunjukkan terdapat hubungan yang signifikan antara minat murid dengan pencapaian Matematik, dapatan menunjukkan minat murid yang tinggi terhadap mata pelajaran matematik akan menghasilkan pencapaian matematik yang tinggi tetapi sekiranya murid tidak mempunyai minat dalam matematik, maka pencapaian Matematik berada pada tahap yang rendah.

\section{Profil Pembelajaran}

Profil pembelajaran murid sangat penting kepada guru dalam menyediakan perancangan pengajaran harian. Santangelo dan Tomlinson (2008) mengutarakan empat faktor penting dalam profil pembelajaran murid iaitu (i) murid berbeza dari aspek gaya belajar, (ii) murid mempunyai pilihan dalam pembelajaran sama ada belajar secara berkumpulan atau secara individu, (iii) murid berbeza keinginan terhadap bentuk pengajaran guru dan (iv) persekitaran pembelajaran sama ada murid-murid sesuai dengan situasi bising atau sebagainya.

Terdapat empat faktor yang membentuk profil pembelajaran, mengikut Tomlinson (2017) terdapat empat faktor yang membentuk profil pembelajaran iaitu (i) gaya belajar, (ii) keutamaan kecerdasan, (iii) jantina dan (iv) budaya. Profil pembelajaran yang difokuskan dalam kajian ini ialah kecerdasan murid, murid mempunyai pelbagai kecerdasan sebagai mana kajian Norizah Tukiman, Abu Bakar Nordin dan Zaharah Hussin (2014) menyatakan banyak kajian yang dijalankan mengaitkan kecerdasan murid di dalam bilik darjah dengan kaedah pengajaran guru. Hal ini selari dengan kehendak Dokumen Standard Kurikulum dan Pentaksiran di mana menyarankan guru-guru menggunakan kecerdasan pelbagai dalam mengimplementasikan pengajaran kepada kepelbagaian murid di bilik darjah (Bahagian Pembangunan Kurikulum, 2018).

Justeru itu, kecerdasan pelbagai yang dibincangkan dikaitkan dengan penggunaan Teori Kecerdasan Pelbagai yang dipelopori oleh Howard Gardner (Gardner, 1983). Garner menyatakan setiap individu mempunyai sembilan kecerdasan iaitu kecerdasan verbal-linguistik, kecerdasan logik-matematik, kecerdasan visual-ruang, kecerdasan kinestetik, kecerdasan muzik, kecerdasan interpersonal, kecerdasan intrapersonal, kecerdasan naturalis dan kecerdasan eksistential (Gardner, 1993).

Kecerdasan pelbagai yang diutarakan oleh Howard Gardner memberi impak yang besar dalam mempengaruhi pembelajaran dan pencapaian murid di mana guru dapat mempraktikkan pelbagai kaedah pengajaran berdasarkan kecerdasan pelbagai murid, hal ini senada dengan kajian Kho Ai Peng, Mohd Asri Mohd Noor dan Nor Azrin Md Latip (2020) terdapat empat domain yang mempengaruhi pencapaian murid dalam mata pelajaran Pengajian Perniagaan iaitu domain kecerdasan verbal linguistik, kecerdasan logik matematik, kecerdasan visual ruang dan kecerdasan interpersonal, manakala terdapat juga domain yang tidak mempengaruhi pencapaian mata pelajaran Pengajian Perniagaan secara signifikan iaitu kecerdasan kinestetik, kecerdasan muzik, kecerdasan intrapersonal dan kecerdasan naturalis. Berdasarkan dapatan kajian lepas menunjukkan kecerdasan pelbagai sangat penting untuk dikenal pasti dalam kalangan murid kerana ia mempengaruhi pembelajaran mereka.

\section{Pedagogi Terbeza (Differentiated Pedagogy)}

Pedagogi Terbeza merupakan salah satu pendekatan pengajaran yang dilaksanakan di dalam bilik darjah yang melibatkan pengubahsuaian kandungan isi pelajaran, proses iaitu strategi pengajaran yang pelbagai serta produk atau hasil kemahiran murid mengikut kebolehan mereka serta persekitaran iaitu 
merujuk kepada keadaan kelas yang kondusif. Tomlinson (2000) menyatakan di dalam Pedagogi Terbeza (Differentiated Pedagogy) guru mengubah suai sekurang-kurangnya empat elemen penting dalam Pedagogi Terbeza (Differentiated Pedagogy) iaitu (i) kandungan di mana isi pelajaran atau kemahiran yang dipelajari oleh murid, (ii) proses yang menunjukkan pengubahsuaian strategi pengajaran yang melibatkan aktiviti-aktiviti pembelajaran, (iii) produk atau hasil di mana hasil-hasil tersebut adalah hasil yang ditunjukkan oleh murid mengikut kebolehan mereka yang pelbagai seterusnya guru menilai hasil tersebut dengan penilaian bersifat holistik dan (iv) persekitaran pula merujuk kepada persekitaran bilik darjah yang memberi keselesaan kepada murid sama ada dari aspek penyusunan kedudukan murid, tampalan maklumat-maklumat di papan-papan kenyataan serta keadaan fasiliti di dalam bilik darjah seperti kipas, lampu dan sebagainya.

Pedagogi Terbeza (Differentiated Pedagogy) juga dikatakan sebagai pedagogi yang mudah lentur dan ia merupakan suatu usaha dalam mempelbagaikan pedagogi mengikut kepelbagaian murid di dalam bilik darjah bagi memberi keadilan kepada semua murid serta murid mendapat hak di dalam mencapai objektif pengajaran dan pembelajaran (Abd. Khahar et al., 2018).

Untuk memberi hak keadilan kepada semua murid yang pelbagai di dalam bilik darjah yang sama, Tomlinson (2008) serta Tomlinson dan B.Imbeau (2014) menyatakan dalam kajian mereka, Pedagogi Terbeza (Differentiated Pedagogy) dilaksanakan di dalam bilik darjah dengan guru mengambil cakna berkaitan kesediaan belajar murid, minat murid serta profil pembelajaran murid sebagai fokus utama sebelum guru merancang pengajaran di dalam bilik darjah.

Hal ini menunjukkan guru meraikan dan menghormati kepelbagaian murid di bilik darjah dengan mengambil kira kaedah pedagogi yang akan dilaksanakan dan guru proaktif membezakan dan mengubah suai isi kandungan kurikulum supaya sesuai dengan kepelbagaian murid yang mempunyai pelbagai aras kemampuan, mengubah suai strategi pengajaran serta menilai hasil murid mengikut kreativiti dan kemampuan mereka, ketiga-tiga aspek ini diubah suai oleh guru dengan mengambil kira kesediaan belajar murid, minat dan profil pembelajaran (Renzulli \& M.Reis, 2014).

Oleh itu, dalam konteks kajian ini, pengkaji mengetengahkan kaedah pengajaran menggunakan Pedagogi Terbeza (Differentiated Pedagogy) dalam memenuhi keperluan murid yang pelbagai di dalam bilik darjah kesan dari pemansuhan streaming kelas dan Pedagogi Terbeza (Differentiated Pedagogy) merupakan kaedah pengajaran yang terbaik untuk diimplementasikan di dalam dunia pendidikan kini.

\section{Pendekatan pengajaran menggunakan Pedagogi Terbeza (Differentiated Pedagogy)}

Pendekatan pengajaran yang bersifat "one-size-fits-all" jelas menunjukkan sudah tidak sesuai dilaksanakan di dalam bilik darjah yang mempunyai murid yang pelbagai (Bondie, Dahnke \& Zusho, 2019). Kaedah pengajaran "one-size-fits-all" harus ditinggalkan memandangkan sudah tidak wujud pengasingan kelas bermula pada tahun 2019 secara kekal kecuali jika ada tujuan yang khusus sahaja pengasingan kelas bersifat sementara dibenarkan (Kementerian Pendidikan Malaysia, 2018). Kesan dari pemansuhan pengasingan kelas, maka akan wujud kepelbagaian murid yang berada di dalam bilik darjah yang sama, kepelbagaian murid ini merujuk kepada kebolehan murid, pencapaian murid yang pelbagai, minat, kesediaan belajar murid, latar belakang murid serta profil pembelajaran murid yang pasti berbeza, Fenomena ini mengundang kepada isu pedagogi guru yang tidak dapat mengawal murid yang pelbagai di bilik darjah, ini senada dengan kajian Tengku Sarina dan Fatimah (2018) yang mendapati terdapat guru yang mempunyai masalah dalam pengurusan murid yang pelbagai di dalam bilik darjah dan sukar untuk mempelbagaikan aktiviti pengajaran kepada murid yang pelbagai.

Melalui kajian-kajian yang dijalankan, kepelbagaian murid di dalam bilik darjah memerlukan kaedah pengajaran yang baharu yang sesuai diaplikasikan kepada semua murid yang pelbagai, hal ini selari dengan dapatan kajian Fairuz et al. (2017) yang mencadangkan supaya elemen Pedagogi Terbeza dimasukkan ke dalam pengajaran guru memandangkan Pedagogi Terbeza dapat meningkatkan serta 
memberi kesan yang positif dan motivasi kepada pelajar pintar berbakat dalam mata pelajaran Biologi. Dapatan kajian ini juga senada dengan dapatan kajian Abdul Razaq et al. (2010) yang menyatakan keperluan kepada kaedah pengajaran yang baharu seperti Pedagogi Terbeza memandangkan murid mempunyai kecenderungan dan gaya belajar yang berbeza tetapi berada di dalam bilik darjah yang sama. Mohamad Marzuqi dan Azmil (2017) dalam kajian pendidikan tahfiz al-Quran di Malaysia juga menyatakan kaedah pengajaran hendaklah sentiasa disesuaikan dengan kebolehan dan kepelbagaian murid dengan mengambil kira faktor minat, kesediaan murid dan profil murid supaya murid beroleh kecemerlangan.

Konsep Pedagogi Terbeza (Differentiated Pedagogy) mula diperkenalkan oleh Carol Ann Tomlinson pada Tahun 1995 di United States of America (USA), konsep ini melibatkan pengajaran guru yang kreatif dan proaktif dalam mengubahsuai kandungan dalam kurikulum seperti mengubah suai sumbersumber pengajaran, kaedah-kaedah pengajaran, penilaian hasil pembelajaran murid yang pelbagai untuk memenuhi dan meraikan kepelbagaian murid di dalam bilik darjah (Tomlinson, 1999). Konsep pengajaran Pedagogi Terbeza digambarkan melalui paparan grafik seperti rajah 1 di bawah.

\section{Rajah 1: Konsep Pedagogi Terbeza (Differentiated Pedagogy)}
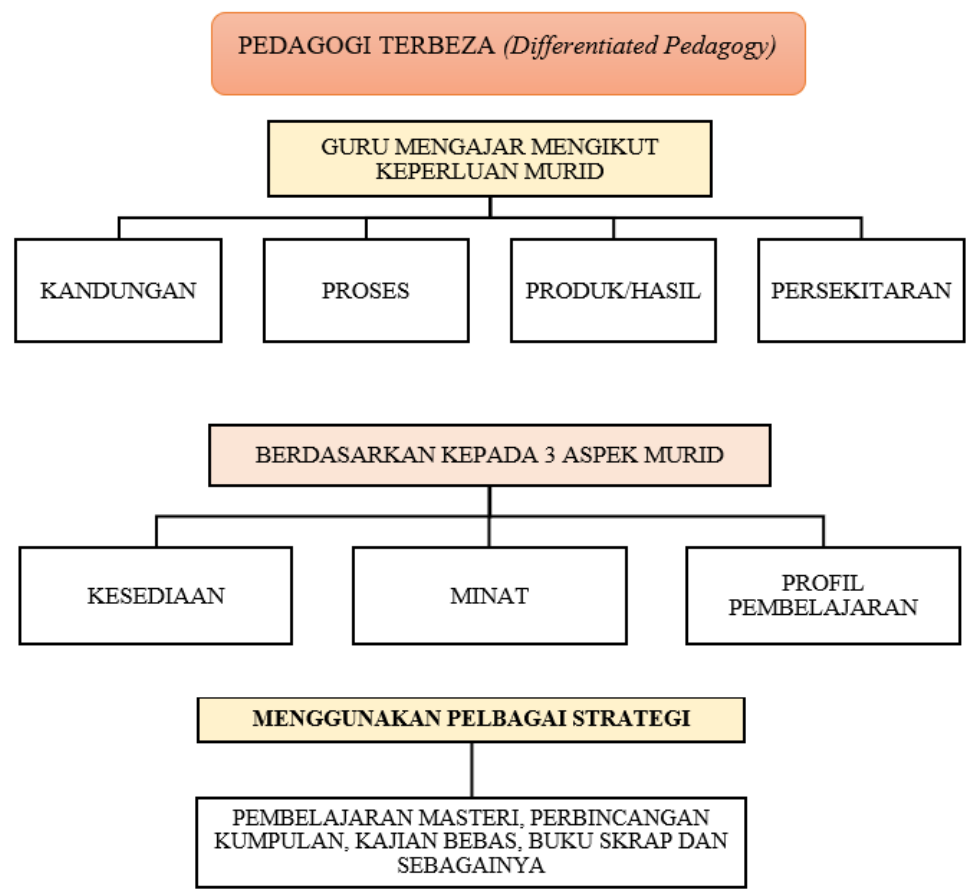

Sumber: Tomlinson (2014)

Rajah 1 di atas menerangkan tentang konsep pengajaran Pedagogi Terbeza (Differentiated Pedagogy) yang diperkenalkan oleh Carol Ann Tomlinson pada tahun 1995, kaedah Pedagogi Terbeza adalah guru mengubah suai salah satu elemen atau ke empat-empat elemen Pedagogi Terbeza iaitu kandungan merujuk kepada kandungan kurikulum yang diubah dari segi sumber-sumber kandungan seperti bahan teks pembelajaran yang berbeza yang mengikut keperluan murid, guru juga boleh mengubah suai proses iaitu kaedah pengajaran yang bersesuaian dengan keperluan murid, manakala elemen produk pula merujuk kepada hasil kemahiran murid yang diperoleh dan ditonjolkan oleh murid serta guru menilainya dan persekitaran merujuk kepada mana-mana tempat pembelajaran yang kondusif serta mendatangkan keselesaan kepada murid, elemen-elemen yang diubah suai oleh guru adalah berdasarkan kepada tiga aspek kepelbagaian murid iaitu kesediaan murid seperti kesediaan dari sudut pengetahuan sedia ada dan pengalaman, minta murid merujuk kepada minat murid tentang konsep isi kandungan pelajaran yang diajar murid dan profil pembelajaran pula merujuk kepada gaya belajar murid, kecerdasan, jantina, latar belakang, budaya dan sebagainya (Rasheed \& Wahid, 2018; Tomlinson, 2017). 
Menerusi konsep Pedagogi Terbeza (Differentiated Pedagogy) ini, jelas menunjukkan ia sesuai untuk dilaksanakan di dalam bilik darjah memandangkan peningkatan kepelbagaian murid di bilik darjah dan ia dapat merapatkan jurang pencapaian antara murid, hal ini selari dengan kehendak Pelan Pembangunan Pendidikan Malaysia (PPPM 2013-2025) di mana terdapat objektif untuk merapatkan jurang pencapaian antara murid perlu dilaksanakan dalam Pembelajaran Abad Ke-21 (PAK 21), tugas guru adalah untuk mengenal pasti potensi murid, memberi fokus kepada pembelajaran murid seterusnya memilih kaedah pedagogi yang sesuai dengan murid (Kementerian Pendidikan Malaysia, 2013).

Justeru itu, Pedagogi Terbeza (Differentiated Pedagogy) wajar digunakan di dalam pengajaran guru di Malaysia memandangkan keperluan pendidikan dalam merapatkan jurang pencapaian serta melahirkan murid yang berpotensi tinggi di tambah lagi kaedah Pedagogi Terbeza telah diimplementasikan di dalam pendidikan luar negara secara meluas seperti di United states of Amerika, Hong Kong, Ethiopia, China dan Indonesia (Coby et al., 2015; Muhamad Nanang \& Valcke, 2016; Silva \& Cestari, 2017; Taylor, 2015). Walau bagaimana pun terdapat sebahagian kajian Pedagogi Terbeza di Malaysia, namun melibatkan sebahagian mata pelajaran sahaja seperti Bahasa Melayu (Daniel, 2020; Roa'ani \& Nor Rul Azlifah, 2019) dan Biologi di pusat Permata Pintar UKM (Fairuz et al., 2017). Oleh yang demikian, wajar dibangunkan Pedagogi Terbeza supaya pendidikan di Malaysia setanding dengan pendidikan global.

Hasil dari pelaksanaan Pedagogi Terbeza (Differentiated Pedagogy) di dalam pendidikan telah menunjukkan terdapat kesan yang positif kepada murid, antaranya hasil dapatan kajian Scigliano \& Hipsky (2010) yang menunjukkan kesan pelaksanaan Pedagogi Terbeza (Differentiated Pedagogy) telah memberi rasa keterpunyaan, keberkesanan diri dan keupayaan diri murid lebih diraikan memandangkan ciri-ciri Pedagogi Terbeza menitik beratkan setiap murid di dalam bilik darjah dan seterusnya dapat mengelakkan keciciran murid di dalam bilik darjah. Selain itu Ginja dan Chen (2020) juga menyatakan melalui Pedagogi Terbeza (Differentiated Pedagogy), murid dapat meningkatkan motivasi kendiri, meningkatkan tabiat belajar dengan memupuk sifat kerjasama dalam kumpulan serta dapat membina hubungan yang harmoni antara guru dengan murid.

Selain dari memberi kesan kepada murid, pengajaran menggunakan kaedah Pedagogi Terbeza (Differentiated Pedagogy), juga dapat membantu sesama guru dalam meningkatkan kaedah pengajaran, hal ini selari dengan dapatan kajian Cihad Senturk (2018) yang menunjukkan pelaksanaan Pedagogi Terbeza (Differentiated Pedagogy), dapat memberi kesedaran kepada guru-guru lain dan dapat berkongsi idea serta pengalaman berkaitan dengan Pedagogi Terbeza (Differentiated Pedagogy), melalui media masa seperti internet dan sebagainya. Situasi ini senada dengan dapatan kajian Daniel (2020) yang menunjukkan terdapat sambutan yang positif dalam kalangan guru Bahasa Melayu untuk mempelajari dan menguasai Pedagogi Terbeza (Differentiated Pedagogy), dengan lebih mendalam bagi memudahkan mereka memahami konsep Pedagogi Terbeza (Differentiated Pedagogy), dengan jelas seterusnya dapat melaksanakan dalam pengajaran di bilik darjah.

\section{Garis Panduan dalam Pedagogi Terbeza (Differentiated Pedagogy)}

Sebelum guru mengubah suai kandungan iaitu isi pelajaran, proses iaitu strategi, teknik pengajaran dan aktiviti-aktiviti pembelajaran dan produk iaitu hasil kemahiran yang diperoleh murid, guru seharusnya memahami beberapa garis panduan di dalam Pedagogi Terbeza sebelum melakukan pengubahsuaian tersebut. Tomlinson (2017) menggariskan enam garis panduan utama dalam Pedagogi Terbeza (Differentiated Pedagogy) iaitu (i) pengajaran guru yang berkesan ialah guru mengenali, memahami dan menilai murid terlebih dahulu diikuti pengajaran kandungan iaitu isi pelajaran, ini kerana murid rasa dihargai, diraikan dan diperhatikan oleh guru mereka, guru yang penyayang dan mengambil berat di dalam bilik darjah lebih mengetahui kehendak dan keperluan murid mereka dalam pelajaran, (ii) guru menerangkan secara jelas kata kunci, generalisasi, prinsip-prinsip, idea-idea utama yang memberi makna dan struktur yang ada pada tajuk pelajaran, kurikulum, unit pelajaran yang dirancang, (iii) guru merancang kaedah dan cara penilaian kepada kemahiran murid, kebiasaannya guru akan menilai murid pada akhir pembelajaran bagi setiap unit pembelajaran, walau bagaimanapun guru boleh merancang 
penilaian murid mengikut kesesuaian dan keperluan serta kebolehan murid, guru boleh merancang penilaian berasaskan pengajaran semasa dan juga boleh melibatkan penilaian murid ke arah kekuatan dan keperluan perkembangan murid, (iv) guru membina proses pengajaran dan pembelajaran yang melibatkan pemikiran kritis dan kreatif murid, tugasan yang diberikan guru sekurang-kurangnya memenuhi keperluan murid yang pelbagai sama ada murid tersebut berada pada tahap penguasaan yang rendah, sederhana mahupun tinggi, paling minima murid dapat memahami apa yang diajar guru, ini kerana terdapat sebahagian murid yang memerlukan bimbingan dalam memahami dan menguasai pelajaran, (v) guru merancang pelajaran agar menarik dan melibatkan semua murid, guru seharusnya merancang pelajaran yang dapat menarik dan melibatkan semua murid sama ada murid tersebut murid yang lemah penguasaannya terhadap mata pelajaran yang diajar mahupun murid yang tinggi penguasaan terhadap pelajaran, hal ini terjadi kerana terdapat murid yang mempunyai masalah, dilema dan isu sama ada di rumah atau di sekolah tetapi berusaha untuk belajar dan (vi) guru mengimbangkan tugas-tugas dan susun atur kerja kepada murid mengikut keperluan dan minat mereka, ini kerana murid berbeza dari segi kematangan, bentuk tugasan dan kerja serta persekitaran keadaan bilik darjah dan sebagainya.

Secara tuntas, matlamat dari garis panduan Pedagogi Terbeza (Differentiated Pedagogy) adalah untuk membantu murid meningkatkan keupayaan dan kebolehan mereka dan guru membantu murid untuk mencapai matlamat dalam pembelajaran secara maksimum dan mengikut perkembangan pertumbuhan murid.

\section{Teori dan Model dalam Pedagogi Terbeza (Differentiated Pedagogy)}

Teori yang digunakan dalam kajian ini ialah Teori Kecerdasan Pelbagai oleh Howard Gardner tahun 1983 (Gardner, 1983) dan Model Pedagogi Terbeza (Differentiated Pedagogy) (Hall, 2002). Pengkaji akan menghuraikan secara terperinci tentang teori dan model yang digunakan dalam kajian ini.

\section{Teori Kecerdasan Pelbagai}

Teori Kecerdasan Pelbagai merupakan teori yang diperkenalkan yang mengutamakan sembilan kecerdasan pelbagai yang ada pada setiap individu iaitu kecerdasan verbal-linguistik, kecerdasan logik-matematik, kecerdasan visual-ruang, kecerdasan kinestetik, kecerdasan muzik, kecerdasan interpersonal, kecerdasan intrapersonal, kecerdasan naturalis dan kecerdasan eksistential (Gardner, 1983). Jacobs (1997) menyatakan murid-murid mempunyai kepelbagaian kebolehan di dalam bilik darjah dan teori Kecerdasan Pelbagai ini meraikan pembezaan kebolehan dan keupayaan murid di bilik darjah. Kecerdasan verbal-linguistik merupakan kecerdasan yang melibatkan gaya belajar murid melalui penerangan lisan, mereka gemar dengan permainan bahasa, teka teki dan cenderung kepada sajak dan puisi (Risky Setiawan, Djemari Mardapi, Aman dan Umum Budi Karyanto, 2020). Manakala gaya belajar kecerdasan logik-matematik pula lebih kepada gaya belajar yang melibatkan penaakulan, membuat perkaitan seperti menyelesaikan masalah dan juga cekap mengira, mereka juga lebih cenderung kepada matematik dan saintifik (Barrington, 2007).

Dalam kajian Sharifah Nasyura (2018) menyatakan kecerdasan visual-ruang pula menunjukkan gaya belajar murid yang cenderung kepada bentuk gambar, garisan dan mampu mempersembahkan idea dalam bentuk grafik, murid yang mempunyai kecerdasan visual-ruang adalah murid yang mempunyai daya imaginasi yang tinggi. Selain itu murid yang mempunyai kecerdasan kinestetik pula lebih gemar melakukan aktiviti secara berkumpulan dan melibatkan pergerakan dan kemahiran fizikal seperti menari, membuat persembahan drama dan bersukan (Risky Setiawan et al., 2020).

Manakala setiap murid mempunyai kecerdasan muzik tetapi tahap kecerdasan muzik yang dimiliki adalah berbeza, hal ini selari dengan kajian Norizah Tukiman et al. (2014) yang menyatakan setiap murid mempunyai kecerdasan muzik namun berbeza bakat yang ada, murid yang cenderung kepada kecerdasan muzik lebih gemar kepada pengajaran secara lisan dan juga suka kepada tarian dan perkara yang berlatar belakang muzik. 
Secara amnya, murid yang memiliki kecerdasan interpersonal adalah murid yang dapat memahami perasaan orang lain dan suka bekerja di dalam bentuk kumpulan, mereka juga seorang yang aktif, mempunyai perasaan empati dan sensitif dengan perasaan orang lain (Siti Rahayah Ariffin, T.Subhan Mohd Meerah, Norasmah Othman dan Ibrahim Mohamed Zin, 2004). Kecerdasan ini berbeza dengan kecerdasan intrapersonal, murid yang memiliki kecerdasan intrapersonal lebih cenderung kepada diri sendiri, membandingkan kekuatan diri dengan orang lain, memahami perasaan sendiri dan mempunyai keyakinan yang tinggi dengan kebolehan diri, walau bagaimana pun murid yang memiliki kecerdasan intrapersonal lebih gemar belajar bersendirian dan tidak suka bersosial serta lebih kepada cenderung belajar secara pemerhatian (Muzarina Juhari et al., 2019).

Kecerdasan naturalis pula merujuk kepada gaya belajar murid yang cenderung kepada tumbuh tumbuhan, bahan galian, haiwan dan secara khususnya mereka lebih gemar kepada alam semula jadi dan lebih cenderung kepada proses pembelajaran di luar bilik darjah (Sharifah Nasyura, 2018). Kecerdasan eksistential pula lebih kepada gaya belajar yang cenderung kepada pembacaan buku-buku falsafah, cenderung kepada menyoal diri seperti penyoalan tentang kematian dan mampu menjawab dengan lebih mendalam (Muzarina Juhari, Ku Suhaila Ku Johari dan MohdIzwan Mahmud, 2019).

Kesimpulannya, kecerdasan pelbagai yang dimiliki oleh murid dapat membantu guru merancang pengajaran dengan lebih berkesan dan dapat meraikan murid yang mempunyai kecenderungan gaya belajar mengikut kecerdasan masing-masing, seperti murid yang mempunyai kecerdasan visual-ruang, guru merancang aktiviti yang melibatkan paparan gambar, tayangan video, membuat rekaan mini grafik, hal ini lebih menarik perhatian murid di bilik darjah dan objektif pengajaran guru tercapai.

\section{Model Pedagogi Terbeza (Differentiated Pedagogy)}

Model Pedagogi Terbeza (Differentiated Pedagogy) telah diperkenalkan oleh Hall pada tahun 2002 (Hall, 2002) di mana terdapat elemen utama Pedagogi Terbeza dalam model ini iaitu kandungan, proses, produk dan persekitaran. Rajah 2 menunjukkan gambaran grafik model Pedagogi Terbeza (Differentiated Pedagogy).

Rajah 2: Model Pedagogi Terbeza (Differentiated Pedagogy)

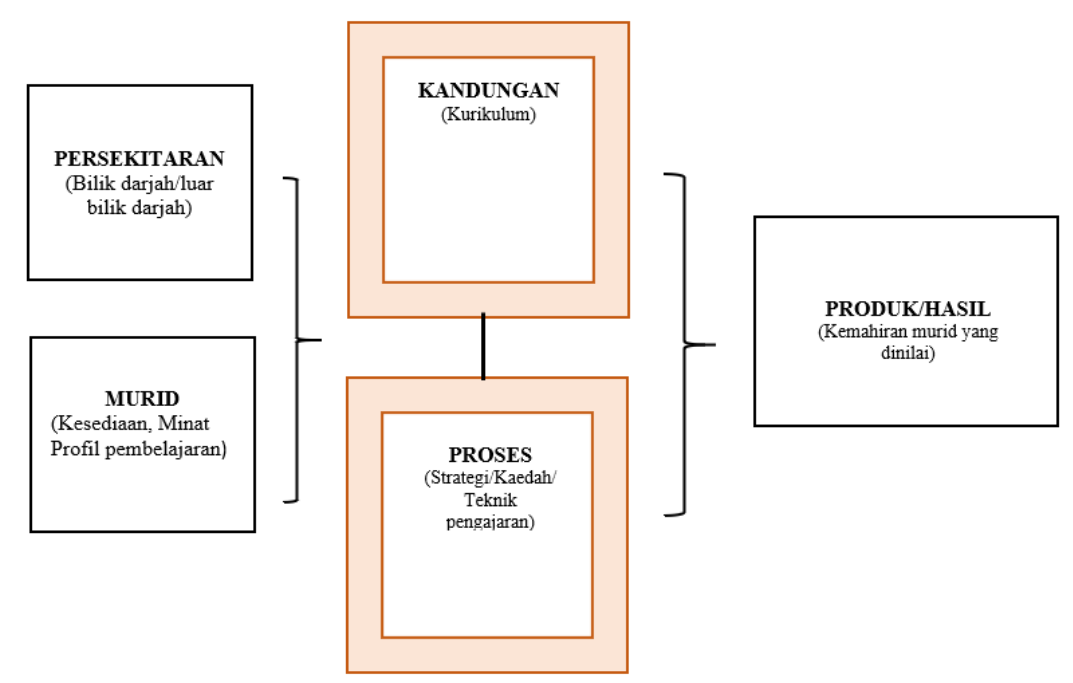

Sumber: Diadaptasi daripada Hall (2002)

Rajah 2 menunjukkan gambaran tentang model Pedagogi Terbeza (Differentiated Pedagogy) yang menunjukkan terdapat elemen penting di dalam model tersebut iaitu kandungan, proses, produk dan persekitaran.

Hall (2002) menyatakan guru-guru mengubah suai kandungan iaitu kurikulum, proses iaitu strategi, kaedah dan teknik pengajaran mengikut kepelbagaian murid yang merangkumi kesediaan, minat dan 
profil pembelajaran murid, manakala produk atau hasil murid pula menunjukkan kemahiran yang dikuasai murid dan dipersembahkan kepada guru untuk dinilai, seterusnya persekitaran juga memainkan peranan yang penting iaitu tempat pembelajaran mengikut keselesaan murid sama ada di bilik darjah atau di luar bilik darjah.

Mengikut Brigandi, Gilson dan Miller (2019), mengubah suai kandungan iaitu kurikulum atau isi pelajaran iaitu guru memadankan isi pelajaran dengan apa yang perlu dipelajari oleh murid seperti memadankan tajuk, konsep, kemahiran atau pun generalisasi mengikut kemampuan murid di bilik darjah sama ada kepelbagaian murid di bilik darjah mempunyai tahap penguasaan kandungan pelajaran yang tinggi atau sebaliknya contoh sekiranya sebahagian murid mempunyai tahap penguasaan yang tinggi, guru akan menyediakan bahan pengajaran yang lebih kompleks kepada golongan tersebut, dan menyediakan bahan yang lebih muda kepada golongan murid yang mempunyai tahap penguasaan yang sederhana dan lemah.

Semasa proses pengajaran pula, guru boleh menggunakan pelbagai strategi, kaedah dan teknik pengajaran yang bersesuaian dengan kepelbagaian murid di bilik darjah, guru boleh menyusun atur murid-murid belajar secara individu atau berada dalam kumpulan yang kecil, kumpulan sederhana besar ataupun mengajar secara keseluruhan kelas dan semua murid terlibat dengan pengubah suaian kandungan pelajaran dengan kaedah pengajaran yang pelbagai (Brigandi et al., 2019). Gregory dan Chapman (2013) menyatakan guru membezakan proses pengajaran mengikut profil pembelajaran murid seperti gaya belajar murid ataupun minat murid seperti pembelajaran tentang mata pelajaran Sejarah, murid boleh membuat peta minda, carian maklumat melalui internet, menemu ramah ahli komuniti dan membina model. Hal ini secara tidak langsung dapat membantu guru mengenal pasti kecenderungan kecerdasan murid dalam pembelajaran sama ada cenderung kepada kecerdasan visualruang, logik-matematik, kinestetik ataupun kecerdasan yang lain (Fordyce, 2021).

Elemen produk dalam model Pedagogi Terbeza (Differentiated Pedagogy) pula menunjukkan hasil pemahaman murid tentang kandungan isi pelajaran yang diajar guru, murid boleh memilih pelbagai cara untuk menunjukkan hasil pemahaman mereka kepada guru seperti menyediakan buku skrap, portfolio, menulis teks, menyampaikan hasil kajian melalui Power Point, menunjukkan hasil temu bual dan sebagainya (Maker dan Shiever, 2005). Manakala Tomlinson (2014) menyatakan produk merupakan hasil yang ditonjolkan oleh murid tentang apa yang mereka dapat serta faham dari penyampaian isi kandungan guru, walau bagaimana pun respons murid kepada persoalan guru tidak dinamakan produk kerana produk adalah hasil kemuncak yang diperoleh murid selepas proses pengajaran dan pembelajaran seperti penghasilan projek, ujian dan persembahan. Menurut Levy (2008) guru membezakan produk dengan memberikan bahan yang berbeza kepada murid mengikut kecenderungan pembelajaran murid iaitu kesediaan belajar murid, minat dan profil pembelajaran dan menilai hasil murid mengikut apa yang murid persembahkan.

Seterusnya elemen persekitaran juga merupakan elemen penting dalam model Pedagogi Terbeza (Differentiated Pedagogy) yang merujuk kepada iklim pembelajaran murid yang kondusif, hal ini selari dengan Maker dan Shiever (2005) yang menyatakan keadaan iklim pembelajaran yang kondusif akan menarik minat murid untuk belajar seperti keadaan bilik darjah yang mempunyai ruangan untuk bahan pembelajaran seperti permainan akademik, majalah akademik dan sebagainya. Persekitaran juga dikaitkan dengan hubungan interaksi sosial murid dengan keadaan susun atur kerusi meja di dalam bilik darjah, unsur-unsur fizikal seperti lampu juga memberi sokongan dan menarik minat murid untuk belajar (Tomlinson \& B.Imbeau, 2014).

Secara keseluruhannya, model Pedagogi Terbeza (Differentiated Pedagogy) merupakan model sandaran yang penting dalam pengajaran menggunakan Pedagogi Terbeza (Differentiated Pedagogy) kepada kepelbagaian murid sekolah rendah memandangkan guru mengubah suai dan membezakan kandungan, proses, produk dan persekitaran mengikut kepelbagaian murid dari segi kesediaan, minat dan profil pembelajaran, pembezaan salah satu elemen atau keempat-empat elemen akan membantu murid untuk menguasai kandungan mengikut kebolehan dan keupayaan mereka malahan melalui model ini dapat membantu guru untuk merancang pengajaran mengikut kecenderungan kecerdasan murid. 


\section{Kesimpulan}

Pedagogi Terbeza (Differentiated Pedagogy) merupakan pendekatan pengajaran yang baharu yang dapat membantu guru menggunakan pelbagai kedah pengajaran kepada kepelbagaian murid yang semakin meningkat dan guru dapat membantu murid dengan merancang pedagogi pengajaran mengikut kecenderungan kecerdasan murid serta dapat menarik minat murid untuk terlibat aktif dan menyumbang idea dalam pembelajaran tanpa berasa rendah diri dan tidak yakin dengan kebolehan serta kemampuan. Melalui Pedagogi Terbeza (Differentiated Pedagogy) juga dapat membantu guru mempelbagaikan kaedah pengajaran dengan lebih berkesan dan meningkatkan penguasaan pemahaman murid dengan tahap yang berbeza sesuai dengan objektif Pelan Pembangunan Pendidikan Malaysia 2013 - 2025 iaitu merapatkan jurang pencapaian murid (Kementerian Pendidikan Malaysia, 2013).

\section{Rujukan}

Al-Quran

Abd. Khahar bin Saprani, Hapsah binti Majid, Zanariah binti Ibrahim, \& Lokman bin Abd Wahid. (2018). Pedagogi terbeza: Keadilan dalam proses pengajaran dan pembelajaran. Jurnal Penyelidikan Pendidikan, 11, 1-17.

Abdul Razaq Ahmad, Anisa Saleha, Zalizan Mohd Jelas, \& Ahmad Ali Seman. (2010). Kepelbagaian pelajar dan sekolah: satu kajian kes di negeri Pahang. Jurnal Pendidikan Malaysia, 35(2), 87-95.

Bahagian Pembangunan Kurikulum. (2018). Dokumen Standard Kurikulum Dan Pentaksiran Pendidikan Islam Tahun 4. In Kementerian Pendidikan Malaysia. Kementerian Pendidikan Malaysia.

Barrington, E. (2007). Teaching to student diversity in higher education: how Multiple Intelligence Theory can help. Teaching in Higher Education, 9(4), 421-434. https://doi.org/10.1080/1356251042000252363

Basirah binti Abu Bakar, Mohd Yakub@Zulkifli bin Mohd.Yusoff, \& Muhamad Ali Hanafiah bin Norasid. (2018). Manhaj al-Quran Mengenai dakwah terhadap remaja: Satu kajian bibliomatrik. QURANICA - International Journal of Quranic Research, 10(2), 89-108.

Bondie, R. S., Dahnke, C., \& Zusho, A. (2019). How Does Changing "One-Size-Fits-All” to differentiated instruction affect teaching? Review of Research in Education, 43(1), 336-362. https://doi.org/10.3102/0091732X18821130

Brigandi, C. B., Gilson, C. M., \& Miller, M. (2019). Professional development and differentiated instruction in an elementary school pullout program: A gifted education case study. Journal for the Education of the Gifted, 42(4). https://doi.org/10.1177/0162353219874418

Carol Ann Tomlinson. (2000). Differentiation of instruction in the elementary grades: differentiation of instruction in the elementary. Early Childhood Education, 7469(4), 1-7.

Cihad Senturk. (2018). Investigation of impacts of differentiated instruction applied in a primary school in attitudes of students towards the course. Cypriot Journal of Educational Sciences, 13(2), 487-505.

Coby Ka-Yau Wu, Sally Wai-Yan Wan, \& Ylena Yan Wong. (2015). Exploring Hong Kong secondry school teachers' teaching belief on differentiated instruction. In Teaching for Tomorrow Today (pp. 158-167).

Daniel Arif Abdul Muttalip. (2020). Pelaksanaan pendekatan pengajaran terbeza dalam kalangan guru Bahasa Melayu yang mengajar di sekolah rendah pedalaman Kategori 3. Jurnal Pendidikan Bahasa Melayu, 10(November), 29-42.

Eka Putri Azrai, Ernawati, \& Gita Sulistianingrum. (2018). Ragam Gaya Belajar Siswa SMA Menurut David Kolb dalam Pembelajaran Biologi. Jurnal Al-Azhar Indonesia Seri Humaniora, 4(4), 251. https://doi.org/10.36722/sh.v4i4.302

Fairuz Adlidna Badrol Hissam, Mohd Hasrul Kamarulzaman, Nurul Suzaina Joli, \& Noriah Mohd Ishak. (2017). Impak pengajaran terbeza ke atas motivasi pelajar pintar dan berbakat di dalam pengajaran dan pembelajaran subjek Biologi. E-Proceeding of the 6Th Global Summit on Education 2017, 2017(December), 174-185. 
Fordyce, F. D. (2021). Teachers' perceptions of differentiation and the struggle for consistent implementation. Walden University.

Gardner, H. (1983). Frames of mind. The theory of multiple intelligences. Basic Book, New York.

Gardner, H. (1993). Multiple intelligences: The theory in Practice. Basic Book: A Division of HarperCollins Publishers, Inc.

Ginja, T. G., \& Chen, X. (2020). Teacher educators' perspectives and experiences towards differentiated instruction. International Journal of Instruction, 13(4), 781-798. https://doi.org/10.29333/iji.2020.13448a

Gregory, G. H., \& Chapman, C. (2013). Differentiated instructional strategies: One size doesn't fit all (third Edit). SAGE Publications Ltd.

Habibah Elias, \& Rahil Mahyudin. (1990). Psikologi Pembelajaran. Dewan Bahasa dan Pustaka.

Hall, T. (2002). Differentiated instruction: Effective classroom practices report. National Center on Accessing the General Curriculum, US Office of Special Education Programs.

Hamir Hamzah Jaafar, \& Mohamad Hilmi Mat Said. (2019). Inovasi pengajaran untuk menarik minat pelajar menguasai ilmu tajwid. International Journal of Humanities Technology and Civilization, 1(6), 1689-1699.

Jacobs, G. (1997). Book reviews: Multiple intelligences in the classroom Thomas Armstrong Alexandria, VA: Association for supervision. RELC Journal, 28(2), 165-171. https://doi.org/10.1177/003368829702800210

Kementerian Pendidikan Malaysia. (2013). Pelan Pembangunan Pendidikan Malaysia 2013 - 2025. In KPM, 27(1). https://doi.org/10.1016/j.tate.2010.08.007

Kementerian Pendidikan Malaysia. (2018a). Info media, menjana maklumat pendidikan (Issue 06).

Kementerian Pendidikan Malaysia. (2018b). Surat siaran Kementerian Pendidikan Malaysia bilangan 14 tahun 2018.

Kho Ai Peng, Mohd Asri Mohd Noor, \& Nor Azrin Md Latip. (2020). Pengaruh kecerdasan pelbagai terhadap pencapaian akademik pelajar bagi subjek Pengajian Perniagaan di Larut Matang dan Selama, Perak. Akademika 90, 90(3), 115-130.

Levy, H. M. (2008). Meeting the needs of all students through differentiated instruction: Helping every child reach and exceed standards. The Clearing House: A Journal of Educational Strategies, Issues and Ideas, 81(4), 161-164. https://doi.org/10.3200/tchs.81.4.161-164

Maker, C. J., \& Shiever, S. W. (2005). Teaching models in education on the gifted (3rd edition). Pro Ed.

Mat Janudin Jamrin. (2002). Keberkesanan penggunaan teknik mengajar peta konsep dalam mata pelajaran Ekonomi Asas tingkatan empat. Universiti Kebangsaan Malaysia.

Mohamad Marzuqi Abdul Rahim, \& Azmil Hashim. (2017). Pendekatan Pengajaran dalam Kalangan Pensyarah Tahfiz Al-Quran di Malaysia. Perspektif: Jurnal Sains Sosial Dan Kemanusiaan (Special Issue), 9(3), 79-88.

Muhamad Nanang Suprayogi, \& Valcke, M. (2016). Differentiated instruction in primary schools: Implementation and challenges in Indonesia. PONTE International Scientific Researchs Journal, 72(6), 1-18. https://doi.org/10.21506/j.ponte.2016.6.1

Muzarina Juhari, Ku Suhaila Ku Johari, \& MohdIzwan Mahmud. (2019). Kecerdasan Pelbagai dan Minat Kerjaya dalam Kalangan Pelajar Sekolah Menengah. Global Conferences Series: Social Sciences, Education and Humanities, 1(9), 133-141.

Noor Erma Abu, \& Leong Kwan Eu. (2014). Hubungan antara sikap, minat, pengajaran guru dan pengaruh rakan sebaya terhadap pencapaian Matematik Tambahan tingkatan 4. Jurnal Kurikulum \& Pengajaran Asia Pasifik, 2(1), 1-10. https://doi.org/10.1140/epjc/s10052-012-2241-5

Noraini Binti Omar, \& Musliha Binti Ismail. (2018). Kemahiran berfikir aras tinggi dalam pengajaran dan pembelajaran berfokuskan kepelbagaian budaya murid sekolah rendah (KSSR). The 5th International Conference on Research in Isamic Education and Arabic Language 2018, 2(1), 72 87.

Norizah Tukiman, Abu Bakar Nordin, \& Zaharah Hussin. (2014). Peningkatan Kemahiran Menghafaz Surah dan Doa Kanak-kanak Prasekolah melalui Pendekatan Berasaskan Teori Kecerdasan Pelbagai. The Online Journal of Islamic Education, 2(1), 114-129.

Nur Hanani Hussin, Mohd Aderi Che Noh, \& Ab. Halim Tamuri. (2013). Elemen Mengenali Murid dalam Pengajaran Guru Cemerlang Pendidikan Islam. The Online Journal of Islamic Education, l(2), 10-19. 
Rahmita Noorbaiti, Noor Fajriah, \& R.Ati Sukmawati. (2018). Implementasi Model Pembelajaran Visual-Auditori-Kinestetik (VAK) pada Mata Pelajaran Matematika di Kelas VII E MTsN Mulawarman Banjarmasin. EDU-MAT: Jurnal Pendidikan Matematika, 6(1), 108-116. https://doi.org/10.20527/edumat.v6i1.5130

Rasheed, F., \& Wahid, A. (2018). The theory of differentiated instruction and its applicabilityan elearning perspective. International Journal of Technical \& Non Technical Researsch, 9(4), 193202.

Renzulli, J. S., \& M.Reis, S. (2014). The schoolwidw enrichment model, a how-to guide for talent development (3rd editio). Prufrock Press Inc.

Risky Setiawan, Djemari Mardapi, Aman, \& Umum Budi Karyanto. (2020). Multiple intelligencesbased creative curriculum: The best practice. European Journal of Educational Research, 9(2), 611-627. https://doi.org/10.12973/eu-jer.9.2.611

Roa'ani Mohamed, \& Nor Rul Azlifah Zulkafali. (2019). Keberkesanan pendekatan pedagogi terbeza (PPT) dalam PdPc bahasa Melayu kelas peralihan: satu kajian tindakan di sebuah sekolah di Kuantan. Journal of Science and Management Research, 68-86.

Santangelo, T., \& Tomlinson, C. A. (2008). The application of diffrentiated instruction ib postsecondry environments: Benefits, challenges, and future directions. International Journal of Teaching and Learning in Higher Education, 20(3), 307-323.

Scigliano, D., \& Hipsky, S. (2010). 3 Ring Circus of Differentiated Instruction. Kappa Delta Pi Record, 46(2), 82-86. https://doi.org/10.1080/00228958.2010.10516699

Sharifah Nasyura. (2018). Hubungan Kecerdasan Pelbagai Guru Sains dengan Kemahiran Berfikir Pelajar. Universiti Putra Malaysia, 3(21), 51-63.

Silva, R. B. da, Moura, \& Cestari, L. A. dos S. (2017). Learning at institution of higher education versus the teacher's role in classroom. American Journal of Educational Research, 5(7), 762769. https://doi.org/10.12691/education-5-7-11

Siti Nurliyana Ab Halim. (2015). Pengetahuan, sikap dan kesediaan pelajar terhadap Kemahiran Berfikir Aras Tinggi (KBAT) dalam pembelajaran pemahaman bacaan. Universiti Kebangsaan Malaysia.

Siti Rahayah Ariffin, T.Subhan Mohd Meerah, Norasmah Othman, \& Ibrahim Mohamed Zin. (2004). Analisis Kecerdasan Pelbagai (Multiple Intelligences) di Kalangan Pensyarah di Sebuah Institusi Pengajian Tinggi (IPT). Jurnal Teknologi, 41, 33-41. https://doi.org/10.11113/jt.v41.725

Taylor, B. K. (2015). Content, process, and product: modeling differentiated instruction. Kappa Delta Pi Record, 51(1), 13-17. https://doi.org/10.1080/00228958.2015.988559

Tengku Sarina Aini Tengku Kasim, \& Fatimah Sahida Abdurajak. (2018). Pengalaman pengajaran guru novis pendidikan Islam : Implikasi terhadap reka bentuk kurikulum latihan pendidikan guru. Jurnal Pendidikan Malaysia, 43(1), 59-66.

Tomlinson, C. A. (1999). Mapping a route toward a differentiated instruction. Educational Leadership, 57(1), 12.

Tomlinson, C. A. (2008). The goals of differentiation. Educational Leadership, 66(3), 26-30.

Tomlinson, C. A. (2014). The differentiated classroom: Responding to the needs of all learners (2nd Edition). ASCD.

Tomlinson, C. A. (2017). Differentiate instruction in academically diverse classroom (3rd edition). Alexandria,VA USA.

Tomlinson, C. A., \& B.Imbeau, M. (2014). Leading and managing a differentiated classroom. In Alexandria, Virginia YSA.

Yulianingsih, D., \& Lumban Gaol, S. M. (2019). Keterampilan guru PAK untuk meningkatkan minat belajar murid dalam proses pembelajaran di kelas. FIDEI: Jurnal Teologi Sistematika Dan Praktika, 2(1), 100-119. https://doi.org/10.34081/fidei.v2i1.47 